\title{
The Arctic Council: a Brief History, its Partnership with Indigenous Groups of the Arctic, and its Role in Uncovering and Addressing Health Issues in the Far North
}

\author{
Kathleen Murray
}

\begin{abstract}
The Arctic Council is an international forum, a venue in which the eight Arctic states can cooperate "...on common Arctic issues, in particular issues of sustainable development and environmental protection." Canada played a major role in the creation of the Council in 1996 and is the Chair of the Council for 2013-2015. The Arctic Council's current focus is on the responsible development of Arctic resources, development of safe Arctic shipping, and supporting sustainable circumpolar communities. Indigenous peoples' organizations from the eight states that participate in the Arctic Council are formally recognized as Permanent Participants and have helped shape the development of the Arctic Council. They also initiate and participate in various projects. Since 2009, the Arctic Council has increasingly focused on health- and wellness-related issues, and its Working Groups and associated project groups have produced data, reports, and documents that are of interest to librarians, clinicians, policy makers, and others concerned with Arctic health. This paper briefly addresses the history, structure, focus, health initiatives, and publications of the Arctic Council. Because of the complex structure and history of the Arctic Council, its publications can be difficult to find, and this report provides helpful tips for obtaining relevant information. The report concludes with some interesting developments in the growing interest by non-Arctic countries wanting to participate in the Arctic Council.
\end{abstract}

\section{Background}

More than four million people who live in the Arctic are citizens of the eight states that participate in the Arctic Council. The Arctic is water surrounded by land that is home to the Inuit, the Aleuts, the Athabascan, the Saami, and the 41 Indigenous groups living in the Russian Federation. In contrast, the Antarctic is land surrounded by water and is the temporary home for a few thousand scientists and researchers in the summer and just a few hundred in the winter. There is a growing awareness of the impacts of climate change on both poles. These changes directly impact the people who live in the North with loss of access to food sources, land erosion causing destruction of homes, and organic pollutants that impact food and human health. This article describes the history, structure, function, and health initiatives of the Arctic Council, a group whose mission includes the well-being of Indigenous peoples living in the North.

\section{History}

Concerns about environmental pollution impacting the health of Indigenous populations living in the Arctic surfaced at the end of the Cold War. Finland led the creation of the Arctic Environmental Protection Strategy (AEPS) in the 1980s in response to persistent organic pollutants that were mainly created by non-Arctic countries but ended up in the food supply of northern peoples. This group focused almost entirely on environmental issues and the enhancement of cooperation amongst Arctic institutions. The AEPS had eight nation-state members, including Canada, and they established four working groups monitored by the states, observers, and Indigenous groups. The following working groups still function as part of the Arctic Council:

- The Arctic Monitoring and Assessment Program (AMAP) monitors and assesses pollutants in the Arctic. They produce assessment reports and recommend responses.

- The Conservation of Arctic Flora and Fauna (CAFF) exchanges information on how Indigenous peoples use and interact with Arctic species.

- The Emergency Prevention, Preparedness, and Response group provides a framework for cooperation in response to environmental emergencies. It created a system of early notification in case of an event.

Kathleen Murray ${ }^{1}$, University of Alaska Anchorage, Alaska Medical Library, 3211 Providence Dr., Anchorage, AK 99524 USA.

${ }^{1}$ Corresponding author (e-mail: kmurray10@uaa.alaska.edu) 
- The Protection of the Arctic Marine Environment (PAME) group conducts activities related to the protection and sustainable use of the arctic marine environment.

Canada, among other nation-state members, wanted to see the AEPS mandate expanded to include economic development for the Arctic. Canada led the effort to merge the existing AEPS working groups into a new organization that would address the broader issue of sustainable development. The United States had issues with some of the structure proposed by Canada but agreed to participate in the newly formed Arctic Council after it was established as a forum without "legal personality," meaning that it is not an "international organization" in terms of international laws [1]. The Declaration on the Establishment of the Arctic Council was signed in Ottawa on 19 September 1996 (the "Ottawa Declaration").

\section{Structure}

The formal structure of the Arctic Council is outlined in the Ottawa Declaration. Understanding the infrastructure of this unique organization will hopefully clarify how their work is done and why finding their publications can be a bit of a detective hunt. There are three categories of participants: States, Permanent Participants, and Observers. Decisions are by consensus of the eight Arctic States in consultation with the Permanent Participants.

The eight states whose ministers meet every two years include Canada, Denmark (Greenland and the Faroe Islands), Finland, Iceland, Norway, Russia, Sweden, and the United States. Each state appoints a Senior Arctic Official (SAO). The SAOs meet every six months and direct the work of the Council on a day-to-day basis. In addition to the eight members, there is a chair of the SAO from the country currently chairing the Council. The current SAO Chair is Patrick Borbey from Canada.

Indigenous peoples living in these eight countries are represented as Permanent Participants. The Ottawa Declaration recognized the role of traditional knowledge of Indigenous peoples in the "collective understanding of the circumpolar Arctic" and committed to the well-being of the inhabitants of the region. The three Indigenous organizations involved with AEPS efforts, the Inuit Circumpolar Conference, the Saami Council, and the Russian Association of Indigenous Peoples of the North (RAIPON), are mentioned as providing valuable support in the development of the Arctic Council. Currently, there are six Permanent Participants: the Inuit Circumpolar Conference, the Saami Council, the RAIPON, the Arctic Athabascan Council, the Gwich'in Council International, and the Aleut International Association. One extremely positive outcome of Permanent Participants having a seat at the table is the focus this brings to the needs and views of Indigenous Arctic residents, particularly issues concerning sustainable development. Permanent Participants can suggest projects and their members participate in the working groups.

An Indigenous Peoples' Secretariat was established in 1994 and this office became part of the Arctic Council framework. Their work is to relay documents and reports between the Permanent Participants and the Council and its Working Groups and they provide coordination for the Indigenous peoples' organizations to meet with each other and participate in the Arctic Council Working Groups.

Observer status is open to non-Arctic states and others. The expectation is that these states and organizations will contribute their knowledge and expertise in multiple ways to the work of the Arctic Council. The current list of observers is on the Arctic Council website (http://www.arctic-council. org/index.php/en/about-us/arctic-council/observers).

The permanent Arctic Council Secretariat opened its doors on 3 June 2013 in Tromsø, Norway. Although having a single administrative base will help smooth the transition between chairmanships that rotate every two years, another reason for its establishment is the need to communicate the findings of the working groups to citizens of the Arctic and to other countries. The primary functions for this office are communication, administration, and translation.

The Arctic Council's working groups are staffed with scientists, researchers, and other experts concerned about issues of immense import to people living in the North. Librarians would be welcomed as contributors to working group activities. I became aware of the Arctic Council and its work when presenting the development of the Arctic Health website to the Council in 2002. This website, managed jointly by the US National Library of Medicine and the Alaska Medical Library at the University of Alaska Anchorage, includes a growing section dedicated to data on the health of Indigenous peoples of the circumpolar Arctic as well as an extensive publications database. I have also supported some of the Council's research efforts by conducting literature searches and hosting the Arctic Human Health Initiative website, described later in this article.

\section{Focus}

The role of the Arctic Council is described by the Ottawa Declaration [2]. Each country, during its chairmanship, develops its own set of priorities for its two-year term. For 2013-2015, during Canada's term, the goals include establishing guidelines for sustainable tourism and cruise ship operations, developing a mandatory polar code (dealing with shipping) for the Arctic Ocean, developing recommendations for incorporating traditional and local knowledge into the work of the Arctic Council, addressing short-lived climate pollutants, promoting mental wellness, and supporting the conservation of migratory birds, a food staple for northern communities. Notable in May 2013, the Arctic states signed an "Agreement on Cooperation on Marine Oil Pollution Preparedness and Response in the Arctic."

Working groups develop projects and conduct research. Ministers, Permanent Participants, and the members of the working groups develop the list of projects; however, Ministers authorize projects.

Human health initiatives are a more recent addition to the work of the Council. Human health in the north is impacted by many factors. It is simplistic to say that only 
two of the working group outcomes should be considered when thinking about human health issues. However, the Sustainable Development Working Group (SDWG) and the Arctic Contaminants Action Program (ACAP) are where many of the Arctic Council's health initiatives live. The SDWG was created at the first Ministerial meeting in 1998. After the SDWG was formed, Canada presented a project focusing on the health and education of children and youth, whereas the United States proposed projects to improve telemedicine services to remote areas in the Arctic and to improve Arctic sanitation systems. The Saami Council presented two proposals related to fisheries management issues. The ACAP was formally given working group status in October 2006.

\section{Health issues: projects and publications}

The addition of specific human health initiatives really expanded during the International Polar Year (2007-2008) as part of the Arctic Human Health Initiative (AHHI), an Arctic Council International Polar Year coordinating project. Abstracts, journal articles, and updates for each of the projects can be found on the AHHI website (http:// www.consortiumlibrary.org/aml/ahhi/proposals/index.htm). The goal of the AHHI was to increase human health research, education, outreach, and communications. The Tromsø declaration of 29 April 2009 acknowledged "the increased focus on human health in the work of the Arctic Council, including the establishment of the new Arctic Human Health Experts Group under the Sustainable Development program" (http://www.arctic-council. org/index.php/en/document-archive/category/5-declarations? download $=38$ :tromso-declaration). Special supplement number six of the International Journal of Circumpolar Health in 2010 describes the 28 projects that have continued under the Arctic Human Health Expert Group (AHHEG) (http://www.circumpolarhealthjournal.net/public/ journals/32/chs/CHS_2010_6.pdf).

The work plan for the AHHEG developed for 20092010 included a list of knowledge gaps and tasks assigned to members of the group: climate change and infections, Saami health and health care, education of health staff, maternal and child health, suicide prevention seminar, documentation of inequalities, and dietary recommendations along with the known health issues presented in Table 1.

Since the Tromsø declaration, a number of projects promoting health and well-being for the peoples of the Arctic have been initiated:

- Comparative Review of Circumpolar Health Systems Report (AHHEG-Canada-Greenland). Phase one of this multi-year project is to assemble national and regional profiles of the different health systems in Arctic countries.

- International Circumpolar Surveillance (ICS) (USA). The ICS established an infectious disease surveillance network of hospital and public health laboratories and authorities throughout Arctic regions to monitor emerging and infectious disease problems. The network collects and shares data between Arctic countries
Table 1. Known health issues for Arctic peoples

\begin{tabular}{|c|c|}
\hline Issue & Cause \\
\hline $\begin{array}{l}\text { Mental health } \\
\text { and suicide }\end{array}$ & $\begin{array}{l}\text { - } \text { marginalization } \\
\text { - depression } \\
\text { - } \text { youth suicides } \\
\text { substance abuse }\end{array}$ \\
\hline $\begin{array}{l}\text { Diet and } \\
\text { nutrition }\end{array}$ & $\begin{array}{l}\text { - food security } \\
\text { - } \text { obesity } \\
\text { - } \text { safe water } \\
\text { - fluoridation } \\
\text { - cardiovascular disease and diabetes }\end{array}$ \\
\hline Health care & $\begin{array}{l}\text { - health care to Indigenous populations } \\
\text { - culturally appropriate health care to the } \\
\text { elderly } \\
\text { - } \text { rapid turn-over of staff } \\
\text { - cultural education of health staff }\end{array}$ \\
\hline $\begin{array}{l}\text { Inequalities in } \\
\text { health }\end{array}$ & $\begin{array}{l}\text { - circumpolar inequalities } \\
\text { - nonexistent documentation for } \\
\text { inequalities }\end{array}$ \\
\hline Other & $\begin{array}{l}\text { - no monitoring of the health effects of } \\
\text { climate change } \\
\text { - infectious diseases (STD, tuberculosis) } \\
\text { - ICS requires expansion } \\
\text { - violence } \\
\text { - child and youth health and wellbeing not } \\
\text { monitored } \\
\text { - tobacco } \\
\text { - unintentional injuries } \\
\text { - more money allocated for health resources } \\
\text { cancer }\end{array}$ \\
\hline
\end{tabular}

and assists in creating prevention and control strategies. It is an activity of the AHHEG.

- Arctic Human Health Minister's Meeting. The meeting was held in Nuuk, Greenland, in February 2011. At this meeting the Ministers recognized the "continued health challenges and noted the need to improve physical and mental health and well-being and empowerment of Indigenous peoples and residents of Arctic communities." (http://www.arctic-council.org/ index.php/en/environment-and-people/arctic-peoples/ health-well-being/166-health)

- Hope and Resilience in Suicide Prevention Seminar (Greenland-Denmark-Canada). This seminar was held in Nuuk, Greenland, on 7-8 November 2009. "This first activity under the auspices of the SDWG AHHEG brought together social workers and health practitioners, researchers, policy makers, and politicians to exchange best practices aimed at reducing the number of suicides in the Arctic countries, particularly among youth. The seminar participants produced recommendations for future actions, a DVD including a video produced by the youth participants, and a seminar report that was translated into Russian with funding provided by Canada." (http://www. arctic-council.org/index.php/en/environment-andpeople/arctic-peoples/health-well-being/166-health)

- Circumpolar Health Observatory (Canada-DenmarkGreenland). This is an international collaborative health information system housed in Yellowknife, Canada. This project monitors trends and patterns 
in health status, health determinants, and health care. The collaborative maintains a searchable and interactive databank of relevant circumpolar human health publications and statistical reports. The website currently contains circumpolar health data for 20002004. Data updates are underway for 2005-2009.

- Circumpolar Nutrition Guide (Canada-DenmarkGreenland). This is an AHHEG project managed by the Greenland Institute for Health Research. Over two years, this group assembled existing information on nutritional guidelines in circumpolar countries. The final report was peer reviewed and published as a Circumpolar Health Supplement in the International Journal for Circumpolar Health in 2011 (http://www. circumpolarhealthjournal.net/public/journals/32/chs/ CHS_2011_8.pdf).

\section{Where is that document?}

Documents are created at the different levels of the Arctic Council: ministerial declarations, working group created assessments and reports, expert group documents, etc. These documents are found in a number of locations on the Council's website and even in remote locations such as the AHHI website. The Arctic Council's home page top navigation bar has a link to the "Document Archive," which includes founding documents and selected other publications grouped by headings such as declarations, Arctic strategies, ministerial meetings, and events. However, many reports and assessments are found within each working group's own website, which are linked from the main Arctic Council website.

AMAP's website has sections for projects, data, and documents. Their documents are grouped into folders labeled assessment reports, technical reports, videos, etc. (http://www.amap.no/documents/18/documents/2). CAFF's website also groups its output by categories such as monitoring (219 documents), assessment (294 documents), or strategies (40 documents) (http://www.caff.is/ publications.) PAME's website lists documents in a document library but also under the latest publications link (http://www.pame.is/).

The SDWG published a number of reports with a health focus during 2009-2011. The full text for each of these documents can be found on the SDWG website (http:// www.sdwg.org/content.php?doc $=23$ ). A sampling of these documents includes the International Circumpolar Surveillance, the Circumpolar Health Systems Review, the report from the Arctic Human Health Initiative, a summary report from the Hope and Resilience in Suicide Prevention Seminar, the Circumpolar Nutrition Guide, and the Survey of Living Conditions in the Arctic (SLiCA).

Given the scattered nature of where documents are housed, here are the suggested steps to track down a specific publication:

(i) Use the search box on the document archive page for the Arctic Council (http://www.arctic-council. org/index.php/en/document-archive). Enter a very simple search. Scroll through the documents and look closely at the filenames, as the "title" may not be obvious. Can't find it here?

(ii) Check the Working Group website. If you believe a working group published a report and you can't find it, use the list of contacts on each working group website. Still no luck?

(iii) If you know when it was published, check the Senior Arctic Official meeting documents for that year (http://www.arctic-council.org/index.php/en/events/ meetings-overview/all-meetings).

(iv) If you don't know when the document might have been created, but you have a good idea of the content, contact the Secretariat. This office has been extremely responsive to my inquiries. They want you to find the information you need and will dig through their files and contacts to help locate their publications (http://www.arctic-council.org/index. $\mathrm{php/en/contact).}$

\section{The future}

Natural resources abound in the Arctic. As a result, a growing number of non-Arctic countries are asking for Observer status. As of the end of 2013, 12 non-Arctic countries have been admitted as Observers to the Arctic Council: France, Germany, The Netherlands, Poland, Spain, United Kingdom, People's Republic of China, Italian Republic, State of Japan, Republic of Korea, Republic of Singapore, and the Republic of India. China, Japan, South Korea, India, Singapore, and Italy all joined in 2013. The European Union's request was put on hold pending further discussion after it launched its own Arctic Study in 2008 without consulting the Arctic Council and banned the import of seal products [1].

Why this interest? The Arctic is facing turbulent times. The Arctic Council has an obvious role. As Young [3] (p. 82) states "The council is not endowed with authority to make formal decisions about public issues on its own. What it does best is to identify emerging issues in a timely manner, provide authoritative assessments regarding important features of these issues, draw them to the attention of non-Arctic specialists, move priority concerns toward the head of the queue on relevant policy agendas, and offer a venue for efforts to address specific concerns."

As medical librarians, we are well served by following the issues addressed by the Arctic Council. Their concerns about food security, infectious diseases, and other health concerns for all who live in the far north, lead to the creation of research and publications that should be shared with our researchers and clinicians. We could also assist these efforts by working within the different working groups providing our expertise in database development, website usability studies, and literature searches. I have reached out to different projects and my offers of help have always been gratefully received.

\section{Acknowledgements}

Many thanks to Tom Fries in the office of the Arctic Council Secretariat. All errors are my own, but this article 
was significantly improved by his explanations, comments, and suggestions.

\section{References}

1. Chaffin J. Canada slows EU entry to Arctic Council. FT.com 29 Apr. 2009.

2. Ottawa Declaration 1996. [Internet]. Arctic Council; 2013 [cited 12 Dec 2013]. Available from: http://www.arctic-council. org/index.php/en/document-archive/category/5-declarations? download =13:ottawa-declaration.

3. Young OR. Arctic tipping points: governance in turbulent times. Ambio. 2012;41(1):75-84. doi: 10.1007/s13280-0110227-4.

\section{Other Resources}

Bloom ET. Establishment of the Arctic Council. Am J Int Law. 1999;93(3):712-22. doi: 10.2307/2555272.

Chaffin J. Canada slows EU entry to Arctic Council. FT.com 2009 Apr. 29.

Charron A. Canada and the Arctic Council. Int'l J. 2012; 67(3):765-83.

Crook JR. United States and other arctic nations conclude first international agreement under Arctic Council auspices. Am J Int Law. 2011;sec. 105:580.

Eicken H, Forbes B, Wiggins H. State of the Arctic conference 2010: international perspectives on progress of research responsive to decision-makers' information needs. Ambio. 2011;40: 824-7. doi: 10.1007/s13280-011-0153-5.

Hands across the ice. The Economist (London). 1996;Sep 21;340(7984):48.

Hitchins DRM. An Alaskan perspective. Int'l J. 2011; 66(4):971-7.

Huebert R. New directions in circumpolar cooperation: Canada, the Arctic Environment Protection Strategy, and the Arctic
Council. Canadian Foreign Policy. 1998;5(2):37-57. doi: 10.1080/11926422.1998.9673131.

Keskitalo C., et al. International region-building: development of the Arctic as an international region. Coop Confl. 2007;42(2): 187-205. doi: 10.1177/0010836707076689.

Koivurova T. Limits and possibilities of the Arctic Council in a rapidly changing scene of Arctic governance. Polar Rec ( $\mathrm{Gr}$ Brit). 2010;46(237):146-56. doi: 10.1017/S0032247409008365.

Koivurova T, Vanderzwaag D. The Arctic Council at 10 years: retrospect and prospects. Univ B C Law Rev. 2007;40(1):121-94.

Krauss S, Hussey KE. Arctic Council plan pushed would link 8 nations in joint effort: $2^{\text {nd }}$ ed. Wash Times. 1995 Jan. 29 A.6.

Milne R. China wins observer status in Arctic Council. FT.com May 15, 2013.

Offerdal K. The EU in the Arctic. Int'l J. 2011;66(4):861-77.

Ottawa Declaration 1996. [Internet]. Arctic Council; 2013 [cited 12 Dec 2013]. Available from: http://www.arctic-council.org/ index.php/en/document-archive/category/5-declarations?download $=13$ :ottawa-declaration.

Pedersen T. Debates over the role of the Arctic Council. Ocean

Development and International Law. 2012;43(2):146-56. doi: 10.1080/00908320.2012.672289.

The roar of ice cracking; outsiders in the Arctic. The Economist (London). 2013 Feb 2: Sect. 406: 49-50.

Staking our Arctic claim. Toronto Star (Canada). 2013 May 14:Sect. A:12.

Stokke OS, Hønneland G. International cooperation and Arctic governance: regime effectiveness and northern region building. London; New York: Routledge, 2006. p. 196.

Webster P. Health in the Arctic Circle. The Lancet. 2005; 365(9461):741-2. doi: 10.1016/S0140-6736(05)18003-9.

Young OR. Arctic tipping points: governance in turbulent times. - Ambio. 2012;41(1):75-84. doi: 10.1007/s13280-011-0227-4. 